\title{
Evaluation of the nutritional status in pre-school and school children, Madeira Island, Portugal
}

\author{
Avaliação do estado nutricional de crianças em idade pré-escolar e escolar, Ilha da Madeira, \\ Portugal
}

\author{
Mafalda Ferreira', Verónica Faria ${ }^{1}$, Bruno Sousa ${ }^{2,3,4}$ Nelson Tavares $^{2,3}$ \\ ${ }^{1}$ Câmara Municipal de Câmara de Lobos, Caminho da Cruz da Caldeira, 30, 9300-401 Câmara de Lobos, Madeira, Portugal. \\ ${ }^{2}$ Escola de Ciências e Tecnologias da Saúde, Universidade Lusófona de Humanidades e Tecnologias, Av. Campo Grande 376, \\ 1749-024 Lisboa, Portugal. \\ ${ }^{3}$ CBIOS (The Research Center for Biosciences \& Health Technologies), Universidade Lusófona de Humanidades e Tecnologias, \\ Av. Campo Grande 376, 1749-024 Lisboa, Portugal. \\ ${ }^{4}$ Serviço de Saúde da Região Autónoma da Madeira, Madeira, Portugal. \\ Email: nelson.tavares@ulusofona.pt
}

\begin{abstract}
In order to evaluate the nutritional status of Câmara dos Lobos Municipality students, all pre-primary and primary public schools located in the municipality were contacted. The assessment of height and body weight, used to calculate body mass index as a method of diagnosing low weight, overweight, or obesity, was performed in 1405 students aged 3 to 9 years. The cut-off points of the BMI adopted by the IOTF were used to calculate the prevalence of underweight, overweight and obesity. The prevalence of underweight, overweight and obesity was $2.5 \%, 36.9 \%$ and $13.1 \%$, respectively. In children between the ages of 3 and 5 the prevalence of overweight (including obesity) is $6.9-12.8 \%$ in boys and 6.9$9.8 \%$ in girls. Six-year-olds had a higher prevalence of overweight when compared to other children. Students from the schools of the Estreito community in Câmara de Lobos presented the highest prevalence of low weight (3.5\%). Students from the community of Curral das Freiras presented a higher prevalence of overweight (42.0\%), and the prevalence of obesity was $21.0 \%$. In order to prevent childhood obesity the municipality of Câmara de Lobos might consider these results for appropriate action.
\end{abstract}

Keywords: Children; Pre-school; School; Nutritional Status; Madeira; Portugal

\section{Resumo}

Para avaliar o estado nutricional dos alunos do Concelho de Câmara dos Lobos, foram contactadas todas as escolas públicas da pré-primária e da primária do município. A avaliação da estatura e do peso corporal, utilizada para cálculo do IMC como método de diagnóstico da existência de baixo peso, excesso de peso ou obesidade, foi realizada em 1405 alunos com idades compreendidas entre 3 e 9 anos. Os pontos de corte do IMC adotados pela IOTF foram utilizados para calcular a prevalência de baixo peso, excesso de peso e obesidade. A prevalência de baixo peso, excesso de peso e obesidade foi de 2,5\%,36,9\% e 13,1\%, respectivamente. Nas crianças entre os 3 e os 5 anos, a prevalência de excesso de peso (incluindo obesidade) varia, respetivamente, entre 6,9 e 12,8\% nos rapazes e entre 6,9 e 9,8\% nas raparigas. Alunos das escolas da freguesia do Estreito de Câmara de Lobos foram os que apresentaram maior prevalência de baixo peso $(3,5 \%)$. Alunos das escolas da freguesia do Curral das Freiras apresentaram maior prevalência de excesso de peso $(42,0 \%)$, sendo a prevalência de obesidade $21,0 \%$. Para prevenir a obesidade infantil, a autarquia deveria considerar os resultados obtidos para definir medidas adequadas.

Palavras-chave: Crianças; Pré-escolar; Escolar; Estado Nutricional; Madeira; Portugal 


\section{Introduction}

The increasing prevalence of childhood obesity is associated with the emergence of comorbidities previously considered as adult diseases, including type 2 diabetes mellitus, hypertension, non-alcoholic fatty liver disease, obstructive sleep apnea and dyslipidemia (1). The worldwide prevalence of childhood obesity has increased notably in the last three decades. It is also one of the main factors in increasing health expenditures (2). For all these reasons, it is important to prevent childhood obesity, as well as identify overweight and obese children at an early stage so that they can start treatment to achieve and maintain a healthy weight (2). The Body Mass Index (BMI) is the most widely used measure of body composition and is defined by body weight divided by height squared $\left(\mathrm{kg} / \mathrm{m}^{2}\right)$. Given its strong association $(r=0.83-0.98)$ with adiposity measurements obtained in children by Dual Energy X-ray Absorptiometry, BMI seems to be an appropriate measure for the indirect assessment of adiposity in childhood (3). Several studies conducted in Germany, France, Finland, Greece, Italy, Switzerland, and Portugal used the BMI cutoffs adopted by the International Obesity Task Force to calculate the prevalence of overweight and obesity (3). In the Autonomous Region of Madeira, some studies have investigated the prevalence of overweight and obesity in childhood, adolescence and young adults, including students from schools in the Autonomous Region of Madeira (4-7). Câmara de Lobos is the second most populous municipality in the Autonomous Region of Madeira, with about 40 thousand inhabitants, with approximately $45 \%$ of the population less than 25 years old. Located in the metropolitan area of Funchal, the municipality of Câmara de Lobos is composed of the parishes of Câmara de Lobos, Estreito de Câmara de Lobos, Curral das Freiras, Quinta Grande and Jardim da Serra. The objective of the present study was to evaluate the prevalence of underweight, overweight and obesity in children of public schools in Câmara de Lobos Municipality aged 3 to 9 years.

\section{Materials and Methods}

All 13 schools located in the Municipality of Câmara de Lobos, in Madeira Island, Portugal, were contacted to participate in this cross-sectional study. The children's inclusion criteria included written parental consent (prepared in accordance with the Declaration of Helsinki), not being sick and being present on the day of

\section{Introdução}

A crescente prevalência de obesidade infantil está associada ao surgimento de comorbilidades anteriormente consideradas como doenças do adulto, incluindo diabetes mellitus tipo 2, hipertensão, fígado gordo não alcoólico, apneia obstrutiva do sono e dislipidemia (1). A prevalência mundial de obesidade infantil aumentou notavelmente nas últimas três décadas. Também é um dos principais factores para o aumento das despesas com a saúde (2). Por todas estas razões, é importante prevenir a obesidade infantil, bem como identificar crianças com excesso de peso e obesidade numa fase precoce para que possam iniciar tratamento para atingir e manter um peso saudável (2). O Índice de Massa Corporal (IMC) é a medida mais utilizada na avaliação da composição corporal sendo definido pelo peso corporal dividido pela altura ao quadrado $(\mathrm{kg} / \mathrm{m} 2)$. Dada a sua forte associação $(r=0,83-98)$ com medidas de adiposidade obtidas em crianças por Absorciometria de Raios-X de Energia Dupla, o IMC parece ser uma medida apropriada para a avaliação indireta da adiposidade na infância (3). Vários estudos realizados na Alemanha, França, Finlândia, Grécia, Itália, Suíça e Portugal utilizaram os pontos de corte de IMC adotados pelo International Obesity Task Force para cálculo das prevalências de excesso de peso e obesidade (3). Na Região Autónoma da Madeira, alguns estudos investigaram a prevalência de excesso de peso e obesidade na infância, adolescência e jovens adultos, incluindo alunos de escolas da Região Autónoma da Madeira (4-7). Câmara de Lobos é o segundo município mais populoso da Região Autónoma da Madeira, com cerca de 40 mil habitantes, tendo aproximadamente $45 \%$ da população menos de 25 anos. Localizado na área metropolitana do Funchal, o município de Câmara de Lobos é composto pelas freguesias de Câmara de Lobos, Estreito de Câmara de Lobos, Curral das Freiras, Quinta Grande e Jardim da Serra. O objetivo do presente estudo foi avaliar a prevalência de baixo peso, excesso de peso e obesidade em crianças de escolas públicas do Concelho de Câmara de Lobos com idade compreendidas entre 3 e 9 anos.

\section{Materiais e métodos}

Foram contatadas as 13 escolas localizadas no Concelho de Câmara de Lobos, na Ilha da Madeira, em Portugal, para participarem neste estudo transversal. Nos critérios de inclusão das crianças constavam o consentimento escrito dos pais (preparado de acordo com a Declaração de Helsínquia), não estar doente e estar pre- 
the scheduled visit to the school by the team conducting the study. The evaluations took place in the 2016/2017 school year. The age of pre-school and primary education in Portugal is established between 3 and 9 years. In the final analysis of the study, only children aged 3.0 to 9.99 years were included to reduce bias in the anthropometric parameters under evaluation. The weight was evaluated using an electronic scale, recording the value to the nearest decigram $(0.1 \mathrm{~kg})$ and during the evaluation, the children had no footwear and light clothing. The stature was assessed using a stadiometer, with the children standing upright, with their backs to the stadiometer and with their feet and knees together, their head positioned so that the gaze remained horizontal, according to the Frankfort plan. The value was recorded to the nearest millimeter $(0.1 \mathrm{~cm})$. The BMI was calculated using the formula Weight $(\mathrm{kg}) /$ Height $\left(\mathrm{m}^{2}\right)(8)$, from the measurements obtained in each child. Overweight and obesity were identified using the international age and gender cut-off points proposed by the International Obesity Task Force (9). SPSS version 20.0 for Windows (Chicago, IL) was used for the statistical treatment of the data. The values of the mean and standard deviation were determined for continuous variables normally distributed and percentage for categorical variables. The Anova Test was used to determine if there were statistically significant differences between the means of Stature, Weight and BMI. Differences between boys and girls were examined using the Fisher's Test. All values of $\mathrm{p}$ obtained were compared with a significance level of $5 \%$.

\section{Results}

Students from the 13 public schools of Câmara de Lobos were invited to participate in a total of 1507, preschool and school, aged between 3 and 11 years. Of these, 1405 children of both sexes (corresponding to $93 \%$ ) of the total were evaluated. In the final analysis of the study, only children aged 3.0 to 9.99 years were included to reduce bias in the anthropometric parameters under evaluation. The percentage distribution of school children by sex and parish is shown in Table 1 . The parish of Câmara de Lobos contributed with the largest number of participating children (585 - 41.6\%). Regarding the distribution by gender and age (Table 2), the highest percentage of boys is in the range of 6.06.99 years $(19.4 \%)$ and girls between $8.0-8.99$ years (19.1\%). The boys had a significantly higher average height than the girls $\mathrm{p}=0.032$ (Table 3 ). The differences between gender and age for weight, height and BMI were statistically significant $(\mathrm{p}<0.05)$. Figure 1 sente no dia da visita programada à escola pela equipa que realizou o estudo. As avaliações tiveram lugar no ano escolar 2016/2017. A idade do ensino pré-escolar e primário em Portugal está estabelecida entre os 3 e os 9 anos. O peso foi avaliado utilizando uma balança eletrónica, registando-se o valor até ao decigrama mais próximo $(0,1 \mathrm{~kg})$ e durante a avaliação, as crianças não tinham calçado e possuíam roupa leve. A estatura foi avaliada utilizando um estadiómetro, com as crianças em posição ereta, de costas para o estadiómetro e com os pés e joelhos juntos, estando a cabeça posicionada para que o olhar se mantivesse horizontal, de acordo com o plano de Frankfort. Registou-se o valor até ao milímetro mais próximo $(0,1 \mathrm{~cm})$. O IMC foi calculado utilizando a fórmula Peso (kg) / Altura (m2) (8), a partir das medidas obtidas em cada criança. $\mathrm{O}$ excesso de peso e a obesidade foram identificados utilizando os pontos de corte internacionais específicos de idade e género propostos pela International Obesity Task Force (9). O SPSS versão 20.0 para Windows (Chicago, IL) foi utilizado para o tratamento estatístico dos dados. Os valores da média e desvio padrão foram determinados para variáveis contínuas normalmente distribuídas e percentagem para variáveis categóricas. O Teste Anova foi usado para determinar se existem diferenças estatisticamente significativas entre as médias de Estatura, Peso e IMC. As diferenças entre rapazes e raparigas foram examinadas usando o Teste de Fisher. Todos os valores de $\mathrm{p}$ obtidos foram comparados com um nível de significância de 5\%.

\section{Resultados}

Foram convidados a participar estudantes das 13 escolas públicas de Câmara de Lobos num total de 1507, da pré-primária e da primária, com idade entre os 3 e 11 anos. Destas foram avaliadas 1405 crianças de ambos os sexos (correspondente a 93\%) do total. $\mathrm{Na}$ análise final do estudo, apenas crianças com idade entre 3,0 e 9,99 anos foram incluídas para reduzir os viés nos parâmetros antropométricos em avaliação. A distribuição percentual das crianças das escolas por sexo e freguesia é mostrada na Tabela 1. A freguesia de Câmara de Lobos contribuiu com o maior número de crianças participantes (585 - 41,6\%). Relativamente à distribuição por sexo e idade (Tabela 2), a maior percentagem de rapazes distribui-se no intervalo entre os 6,0-6,99 anos (19,4\%) e as raparigas entre os 8,0-8,99 anos $(19,1 \%)$. Os rapazes apresentaram uma estatura média significativamente mais elevada que as raparigas $\mathrm{p}=0.032$ (Tabela 3 ). As diferenças entre género e idade para peso, estatura e 
shows the distribution of the nutritional status of children, as defined by the International Obesity Task Force (IOTF), the prevalence of underweight, overweight and obesity were $2.5 \%, 36.9 \%$ and $13.1 \%$ respectively. As shown in Table 4,according to the IOTF criteria, the 6-year-old students had the highest prevalence of overweight (without statistical significance). Girls had a higher prevalence of underweight (5-9 years) and overweight (6-9 years), although not statistically significant. Table 5 shows the distribution of children by urban and semi-urban parishes, showing that the students of the urban parish of Estreito de Câmara de Lobos had the highest prevalence of low weight $(3.49 \%)$. As for overweight (including obesity), the semi-urban parish of Curral das Freiras presented values of higher prevalence $(41.94 \%)$, as well as obesity $(20.97 \%)$, with statistical significance.
IMC foram estatisticamente significativas $(\mathrm{p}<0,05)$. A Figura 1 apresenta a distribuição do estado nutricional das crianças, definido pela International Obesity Task Force (IOTF), a prevalência de baixo peso, excesso de peso e obesidade foram de $2,5 \%, 36,9 \%$ e $13,1 \%$, respectivamente. Na Tabela 4, verificou-se de acordo com os critérios da IOTF que os alunos com 6 anos eram aqueles que apresentavam prevalência mais elevada de excesso de peso (sem significância estatística). As raparigas apresentaram maior prevalência de baixo peso (5-9 anos) e excesso de peso (6-9 anos), embora sem significado estatístico.

$\mathrm{Na}$ Tabela 5 é apresentada a distribuição das crianças por freguesias urbanas e semi-urbanas verificando-se que os alunos da freguesia urbana Estreito de Câmara de Lobos foram os que apresentaram maior prevalência de baixo peso (3,49\%). Quanto ao excesso de peso (incluindo a obesidade), a freguesia semi-urbana Curral das Freiras apresentou valores de maior prevalência (41,94\%), assim como de obesidade (20,97\%), sem significância estatística.

Table 1/ Tabela 1 - Distribution of schoolchildren by gender and parish/ Distribuição das crianças por sexo e freguesia

\begin{tabular}{|l|c|c|c|c|c|c|c|}
\hline \multicolumn{2}{|c|}{ Gender/Sexo } & $\begin{array}{c}\text { Câmara de } \\
\text { Lobos }\end{array}$ & $\begin{array}{c}\text { Curral das } \\
\text { Freiras }\end{array}$ & $\begin{array}{c}\text { Estreito da } \\
\text { Câmara de } \\
\text { Lobos }\end{array}$ & $\begin{array}{c}\text { Quinta } \\
\text { Grande }\end{array}$ & $\begin{array}{c}\text { Jardim da } \\
\text { Serra }\end{array}$ & Total \\
\hline \multirow{2}{*}{ Boys/Rapazes } & $\mathrm{n}$ & 288 & 30 & 261 & 62 & 61 & 702 \\
\cline { 2 - 8 } & $\%$ & 49.2 & 48.4 & 50.6 & 51.7 & 50.0 & 50.0 \\
\hline \multirow{2}{*}{ Girls/Raparigas } & $\mathrm{n}$ & 297 & 32 & 255 & 58 & 61 & 703 \\
\cline { 2 - 8 } & $\%$ & 50.8 & 51.6 & 49.4 & 48.3 & 50.0 & 50.0 \\
\hline \% Total & & 41.6 & 4.4 & 36.78 & 8.5 & 8.7 & 100 \\
\hline
\end{tabular}


Table 2/ Tabela 2 - Distribution of schoolchildren by gender and age/

Distribuição das crianças por sexo e idade

\begin{tabular}{|c|c|c|c|c|c|c|}
\hline \multirow{2}{*}{$\begin{array}{l}\text { Age } \\
\text { (years)/Idade } \\
\text { (anos) }\end{array}$} & \multicolumn{2}{|c|}{ Boys/Rapazes } & \multicolumn{2}{|c|}{ Girls/Feminino } & \multicolumn{2}{c|}{ Total } \\
\cline { 2 - 7 } & $\mathrm{n}$ & $\%$ & $\mathrm{n}$ & $\%$ & $\mathrm{n}$ & $\%$ \\
\hline $3.00-3.99$ & 40 & 5.7 & 51 & 7.2 & 91 & 6.4 \\
\hline $4.00-4.99$ & 58 & 8.3 & 73 & 10.4 & 131 & 9.3 \\
\hline $5.00-5.99$ & 94 & 13.4 & 98 & 13.9 & 192 & 13.7 \\
\hline $6.00-6.99$ & 136 & 19.4 & 108 & 15.4 & 244 & 17.4 \\
\hline $7.00-7.99$ & 119 & 17.0 & 103 & 14.7 & 222 & 15.8 \\
\hline $8.00-8.99$ & 133 & 18.9 & 135 & 19.2 & 268 & 19.1 \\
\hline $9.00-9.99$ & 122 & 17.3 & 135 & 19.2 & 257 & 18.3 \\
\hline Total & 702 & 50.0 & 703 & 50.0 & 1405 & 100.0 \\
\hline
\end{tabular}

Overweight+Obesity / Excesso de peso+Obesidade

Obesity/ Obesidade

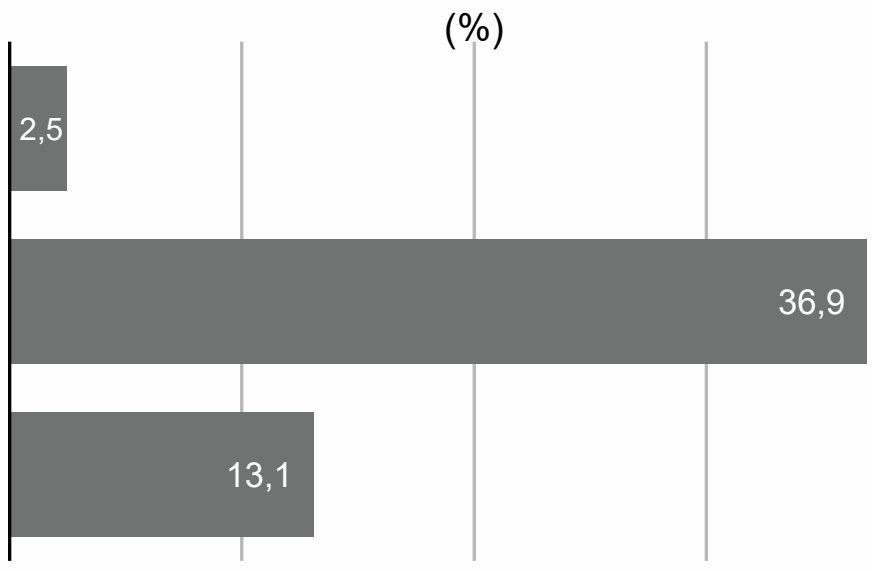

0, $\quad 10, \quad 20, \quad 30, \quad 40$,

Figure 1/ Figura 1 - Nutritional status according to IOTF criteria/ Estado Nutricional de acordo com os critérios da IOTF 
Table3 /Tabela 3 - Anthropometric evaluation according to gender and age/ Avaliação antropométrica por sexo e idade

\begin{tabular}{|c|c|c|c|c|c|c|c|}
\hline & & Height/E & tura (m) & Weight/ & o (kg) & BMI/ IN & $\left(\mathrm{kg} / \mathrm{m}^{2}\right)$ \\
\hline & & $\begin{array}{l}\text { Mean } \pm \\
\text { SD/Média } \\
\pm \text { DP }\end{array}$ & $\begin{array}{l}p \text {-value } \\
0.032 *\end{array}$ & $\begin{array}{l}\text { Mean } \pm \text { SD/ } \\
\text { Média } \pm \text { DP }\end{array}$ & $\begin{array}{c}p \text {-value } \\
0,264\end{array}$ & $\begin{array}{l}\text { Mean } \pm \text { SD/ } \\
\text { Média } \pm \text { DP }\end{array}$ & $\begin{array}{c}p \text {-value } \\
\\
0.868\end{array}$ \\
\hline \multirow{2}{*}{$\begin{array}{c}\text { Gender/Sex } \\
\text { o }\end{array}$} & \multirow{2}{*}{\begin{tabular}{|c}
$\begin{array}{c}\text { Boys/Rapa } \\
\text { zes }\end{array}$ \\
$\begin{array}{c}\text { Girls/Femi } \\
\text { nino }\end{array}$
\end{tabular}} & $1.240 \pm 0.1$ & \multirow{2}{*}{$0.032 *$} & $\begin{array}{c}27.840 \pm \\
9.0\end{array}$ & \multirow{2}{*}{0,264} & $\begin{array}{c}17.860 \pm \\
3.3\end{array}$ & \multirow{2}{*}{0.868} \\
\hline & & $1.220 \pm 0.1$ & & $\begin{array}{c}27.310 \pm \\
8.8\end{array}$ & & $\begin{array}{c}17.830 \pm \\
3.4\end{array}$ & \\
\hline \multirow{7}{*}{$\begin{array}{c}\text { Age(years)/ } \\
\text { Idade } \\
\text { (anos) }\end{array}$} & 3 & $\begin{array}{c}0.989 \pm \\
0.04\end{array}$ & \multirow{7}{*}{0.000} & $\begin{array}{c}16.634 \pm \\
0.6\end{array}$ & \multirow{7}{*}{0.000} & $16.88 \pm 0.6$ & \multirow{7}{*}{0.000} \\
\hline & 4 & $\begin{array}{c}1.066 \pm \\
0.03\end{array}$ & & $\begin{array}{c}19.000 \pm \\
0.7\end{array}$ & & $16.63 \pm 0.4$ & \\
\hline & 5 & $\begin{array}{c}1.141 \pm \\
0.04\end{array}$ & & $\begin{array}{c}22.300 \pm \\
3.7\end{array}$ & & $\begin{array}{c}16.99 \pm \\
2.26\end{array}$ & \\
\hline & 6 & $1.198 \pm 0.1$ & & $\begin{array}{c}25.200 \pm \\
5.5\end{array}$ & & $17.46 \pm 2.7$ & \\
\hline & 7 & $1.262 \pm 0.1$ & & $\begin{array}{c}28.900 \pm \\
7.0\end{array}$ & & $17.96 \pm 3.3$ & \\
\hline & 8 & $1.321 \pm 0.1$ & & $\begin{array}{c}32.700 \pm \\
7.8\end{array}$ & & $18.56 \pm 3.3$ & \\
\hline & 9 & $1.364 \pm 0.1$ & & $\begin{array}{c}35.600 \pm \\
8.5\end{array}$ & & $18.95 \pm 3.4$ & \\
\hline
\end{tabular}


Table 4/ Tabela 4 - Nutritional status by age and gender according to IOTF criteria/ Estado nutricional por idade e sexo, de acordo com os critérios da IOTF

\begin{tabular}{|c|c|c|c|c|c|}
\hline $\begin{array}{c}\text { Age(years)/Ida } \\
\text { de(anos) }\end{array}$ & $\begin{array}{l}\text { Gender/S } \\
\text { exo }\end{array}$ & $\begin{array}{c}\text { Low weight/ } \\
\text { Baixo peso } \\
\text { n (\%) }\end{array}$ & $\begin{array}{c}\text { Overweight } \\
\text { (including obesity)/ } \\
\text { Excesso de Peso } \\
\text { n (\%) }\end{array}$ & $\begin{array}{c}\text { Obesity/ Obesidade } \\
\text { n (\%) }\end{array}$ & $p$-value \\
\hline \multirow{2}{*}{3} & $\begin{array}{c}\text { Boys/ } \\
\text { Rapazes }\end{array}$ & $0(0.0)$ & $4(10.00)$ & $2(5.00)$ & \multirow{2}{*}{0.504} \\
\hline & $\begin{array}{c}\text { Girls/ } \\
\text { Feminino }\end{array}$ & $0(0.0)$ & $5(9.80)$ & $1(1.96)$ & \\
\hline \multirow{2}{*}{4} & $\begin{array}{c}\text { Boys/ } \\
\text { Rapazes }\end{array}$ & $1(1.7)$ & $4(6.90)$ & $2(3.45)$ & \multirow{2}{*}{0.574} \\
\hline & $\begin{array}{c}\text { Girls/ } \\
\text { Feminino }\end{array}$ & $0(0.0)$ & $5(6.85)$ & $2(2.74)$ & \\
\hline \multirow{2}{*}{5} & $\begin{array}{c}\text { Boys/ } \\
\text { Rapazes }\end{array}$ & $1(1.06)$ & $12(12.77)$ & $9(9.57)$ & \multirow{2}{*}{0.291} \\
\hline & $\begin{array}{c}\text { Girls/ } \\
\text { Feminino }\end{array}$ & $3(3.06)$ & $9(9.18)$ & $4(4.08)$ & \\
\hline \multirow{2}{*}{6} & $\begin{array}{c}\text { Boys/ } \\
\text { Rapazes }\end{array}$ & $1(0.74)$ & $21(15.44)$ & $11(8.09)$ & \multirow{2}{*}{0.352} \\
\hline & $\begin{array}{c}\text { Girls/ } \\
\text { Feminino }\end{array}$ & $2(1.85)$ & $17(15.74)$ & $6(5.56)$ & \\
\hline \multirow{2}{*}{7} & $\begin{array}{c}\text { Boys/ } \\
\text { Rapazes }\end{array}$ & $1(0.84)$ & $17(14.29)$ & $9(7.56)$ & \multirow{2}{*}{0.893} \\
\hline & $\begin{array}{c}\text { Girls/ } \\
\text { Feminino }\end{array}$ & $1(0.97)$ & $22(21.36)$ & $10(9.71)$ & \\
\hline \multirow{2}{*}{8} & $\begin{array}{c}\text { Boys/ } \\
\text { Rapazes }\end{array}$ & $0(0.0)$ & 19 (14.29) & $7(5.26)$ & \multirow{2}{*}{0.678} \\
\hline & $\begin{array}{c}\text { Girls/ } \\
\text { Feminino }\end{array}$ & $1(0.74)$ & $24(17.78)$ & $9(6.67)$ & \\
\hline \multirow{2}{*}{9} & $\begin{array}{c}\text { Boys/ } \\
\text { Rapazes }\end{array}$ & $1(0.82)$ & $12(9.84)$ & $3(2.46)$ & \multirow{2}{*}{0.763} \\
\hline & $\begin{array}{c}\text { Girls/ } \\
\text { Feminino }\end{array}$ & $2(1.48)$ & $16(11.85)$ & $7(5.19)$ & \\
\hline
\end{tabular}


Table 5/ Tabela 5 - Nutritional status of children by parish (urban and agricultural-urban), according to IOTF criteria/ Estado nutricional das crianças por freguesia (urbanas e semiurbanas), de acordo com os critérios da IOTF

\begin{tabular}{|c|c|c|c|}
\hline & Low weight/ Baixo Peso & $\begin{array}{l}\text { Overweight (including } \\
\text { obesity)/ Excesso de } \\
\text { Peso (incluindo } \\
\text { obesidade) }\end{array}$ & Obesity/ Obesidade \\
\hline $\begin{array}{c}\text { Urban parish/ Freguesias } \\
\text { urbanas }\end{array}$ & \multicolumn{3}{|c|}{$\%$} \\
\hline Câmara de Lobos & 2.39 & 32.31 & 13.68 \\
\hline $\begin{array}{c}\text { Estreito de Câmara de } \\
\text { Lobos }\end{array}$ & 3.49 & 35.27 & 13.18 \\
\hline $\begin{array}{c}\text { Agricultural-urban } \\
\text { parish/ Freguesias semi- } \\
\text { urbanas }\end{array}$ & \multicolumn{3}{|c|}{$\%$} \\
\hline Curral das Freiras & 1.61 & 41.94 & 20.97 \\
\hline Quinta Grande & 0.00 & 36.67 & 12.50 \\
\hline Jardim da Serra & 2.46 & 36.89 & 13.11 \\
\hline Total & 2.28 & 34.59 & 13.67 \\
\hline
\end{tabular}

\section{Discussion}

To the best of authors' knowledge, this is the first study to evaluate the prevalence of underweight, overweight and obesity in children aged 3 to 9 years in the Autonomous Region of Madeira. There are few studies carried out in Portugal that evaluate the prevalence of overweight (including obesity) in pre-school and school children. This study also contributes to the knowledge, in particular, of low weight and overweight (including obesity) in children aged between 3 and 5 years. Some of the highest levels of obesity in the world are found in island populations (10-14). One of the most important factors influencing the prevalence of overweight

\section{Discussão}

De acordo com o conhecimento dos autores este é o primeiro estudo que avalia a prevalência de baixo peso, excesso de peso e obesidade em crianças com idades compreendidas entre os 3 e os 9 anos na Região Autónoma da Madeira. São poucos os estudos realizados em Portugal que avaliem a prevalência de excesso de peso (incluindo obesidade) com crianças em idade pré-escolar e escolar. Este estudo contribui também com o conhecimento, em particular, sobre o baixo peso e excesso de peso (incluindo obesidade) em crianças dos 3 aos 5 anos. Alguns dos mais elevados níveis de obesidade no mundo são encontrados nas populações de ilhas (10- 
and obesity in children is socioeconomic status (15). Evidence suggests that food costs, among other factors, may be associated with obesity-related health disparities, especially among disadvantaged populations (16, 17). The municipality of Câmara de Lobos has a very low purchasing power indicator at the national level of 57.25 , according to a study of the National Statistical Institute for 2015 on purchasing power in Portugal (18). It included children from two urban areas, the parishes of Câmara de Lobos and Estreito de Câmara de Lobos, and three semi-urban areas, Jardim da Serra, Curral das Freiras and Quinta Grande parishes. The semi-urban parish of Curral das Freiras presented values of higher prevalence of overweight (41.94\%), as well as obesity (20.97\%), with no statistical significance. In the evaluation of the Local Development Strategy for the period 2007-2013, the illiteracy rate of the Curral das Freiras parish was the highest in Câmara de Lobos (19). There are evidences that low levels of health literacy are associated with overweight, particularly in children (20). Recent data show alarming numbers of obese and overweight children of pre-school age (21). In 2010, 43 million children under the age of five were obese or overweight worldwide and the prevalence was estimated to increase from $6.7 \%$ to $9.1 \%$ by 2020 (22). In this study, the prevalence of overweight (including obesity) varies between $6.9 \%$ and $10 \%$ in children aged 3 and 4 years. These figures go beyond the aforementioned forecasts of $9.1 \%$ for the year 2020 . However, these results are lower than those obtained in a study carried out in Vila Nova de Gaia (23) using the IOTF criteria. Another study (24) which also used the IOTF criteria, aimed to combine available information on the prevalence of overweight (including obesity) in European children, aged 3 and 4 years were from 7\% (Belgium) to $33.2 \%$ (Spain). The results obtained in this study for children aged 7-9 years, with respect to the prevalence of overweight (including obesity), vary between 9.8\% and $14.3 \%$ respectively in boys and between $11.9 \%$ and $21.4 \%$ in girls. In another study in Madeira, published in 2009 using the IOTF criteria (4), the prevalence found for overweight (including obesity) for children aged 7 to 9 years was $11.4 \%$ to $16.9 \%$ for boys and from $14.7 \%$ to $23.4 \%$ for girls. There was a decrease in the prevalence of overweight (including obesity) in their comparison. In the municipality of Câmara dos Lobos, for children between 6 and 9 years old, the prevalence of underweight, overweight and obesity are also in line with values obtained in an earlier study carried out in Madeira (5).

The evaluation of children's lifestyle behaviors including eating habits, physical activity and sed-
14). Um dos fatores mais importantes que influenciam a prevalência de excesso de peso e obesidade em crianças é o status socio-económico (15). Evidências sugerem que o custo dos alimentos, entre outros fatores, pode estar associado a disparidades de saúde relacionadas com a obesidade especialmente em populações desfavorecidas $(16,17)$. O município de Câmara de Lobos apresenta a nível nacional um indicador de poder de compra muito baixo que se situa em 57,25 , segundo um estudo do Instituto Nacional de Estatística, relativo a 2015, sobre o poder de compra em Portugal (18). Incluiu crianças de duas áreas urbanas, as freguesias de Câmara de Lobos e do Estreito de Câmara de Lobos e três áreas semi-urbanas as freguesias Jardim da Serra, Curral das Freiras e Quinta Grande. A freguesia semi-urbana Curral das Freiras apresentou valores de maior prevalência de excesso de peso $(41,94 \%)$, assim como de obesidade (20,97\%), sem significado estatístico. Na avaliação da Estratégia Local de Desenvolvimento do período 20072013, a taxa de analfabetismo da freguesia do Curral das Freiras era a mais elevada do concelho da Câmara de Lobos (19). Existem evidências que baixos níveis de literacia para a saúde estão associados a excesso de peso, particularmente em crianças (20).

Dados recentes mostram números alarmantes de crianças obesas e com excesso de peso em idade pré-escolar (21). Em 2010, 43 milhões de crianças com menos de cinco anos estavam obesas ou com excesso de peso em todo o mundo e estimava-se que a prevalência aumentasse de $6,7 \%$ para $9,1 \%$ em 2020 (22). Neste estudo, em crianças de 3 e 4 anos a prevalência de excesso de peso (incluindo obesidade) varia, respetivamente, entre $6,9 \%$ e $10 \%$. Estes valores ultrapassam já as previsões referidas de $9,1 \%$ para o ano 2020. Porém, quando comparados com os resultados obtidos num estudo realizado em Vila Nova de Gaia (23) que utilizou os critérios da IOTF, estes são inferiores. Outro estudo (24) que teve como objetivo sintetizar informações disponíveis sobre prevalência de excesso de peso (incluindo obesidade) em crianças na Europa, que também utilizou os critérios da IOTF, a prevalência de excesso de peso (incluindo obesidade) para crianças de 3 e 4 anos foi de 7\% (Bélgica) a 33,2 \% (Espanha). Os resultados obtidos relativos a crianças, participantes neste estudo, com idades compreendidas entre os 7 e 9 anos no que diz respeito à prevalência de excesso de peso (incluindo obesidade) variam, respetivamente, entre 9,8\% e 14,3\% nos rapazes e entre $11,9 \%$ e $21,4 \%$ nas raparigas. Noutro estudo, publicado em 2009 que utilizou os critérios da IOTF, realizado na Madeira (4) a prevalência encontrada para excesso de peso (incluindo obesidade) para crianças dos 7 aos 9 anos foi de $11,4 \%$ a $16,9 \%$ para os 
entary behaviors were not evaluated in this study, which was a limitation of this study of this study. The knowledge of the existence of overweight in the age group between 3 and 5 years may contribute to prevent the development of excess weight, which may be influenced by the characteristics of the child and the risk factors to which they are exposed, such as parental practices with regard to food and family and demographic, social and community characteristics (25). The importance of the municipalities (26) in the promotion of healthy eating and in the prevention of childhood obesity was recognized and, therefore, this study on the prevalence of overweight and obesity among children of the public schools of Câmara dos Lobos Municipality provides information that can be used by local authorities to take adequate measures against obesity in the different parishes of this municipality.

\section{Conflict of interests}

The authors declare that they do not have any type of relationship likely to have a potential conflict of interest. rapazes e de $14,7 \%$ a $23,4 \%$ para as raparigas. Houve uma diminuição dos valores da prevalência do excesso de peso (incluindo a obesidade) na comparação dos mesmos. No Concelho de Câmara dos Lobos, para as crianças entre os 6 e os 9 anos, a prevalência de baixo peso, excesso de peso e obesidade estão em linha também com valores obtidos num estudo anterior realizado na Madeira (5).

A avaliação dos comportamentos de estilo de vida das crianças que incluem os hábitos alimentares, a atividade física e os comportamentos sedentários não foram avaliados neste estudo, o que constituiu uma das limitações deste estudo. O conhecimento da existência de excesso de peso na faixa etária entre os 3 e os 5 anos pode vir a contribuir para evitar o desenvolvimento do excesso de peso que, pode ser influenciado pelas características da criança e os factores de risco a que está exposta, como as práticas parentais no que diz respeito à alimentação e as características familiares e demográficas, sociais e comunitárias (25). Foi reconhecida a importância das Autarquias (26) na promoção de uma alimentação saudável e na prevenção da obesidade infantil e assim, este estudo sobre a prevalência de excesso de peso e obesidade entre crianças das escolas públicas do Concelho de Câmara dos Lobos fornece informações que podem ser utilizadas pelas autoridades locais para tomar as medidas adequadas no combate à obesidade nas diferentes freguesias do seu concelho.

\section{Conflito de interesses}

Os autores declaram que não têm nenhum tipo de relacionamento susceptível de ter um potencial conflito de interesses. 


\section{References/ Referências}

1. Kumar, Seema et al. Review of Childhood Obesity. Mayo Clinic Proceedings , 2017.Volume 92 , Issue 2, 251 - 265.

2. Gungor NK. Overweight and Obesity in Children and Adolescents. Journal of Clinical Research in Pediatric Endocrinology, 2014. 6(3), 129-143. http:// doi.org/10.4274/jcrpe.1471

3. Tokmakidis, Savvas P. et al. Validity of Self-Reported Anthropometric Values Used to Assess Body Mass Index and Estimate Obesity in Greek School Children. Journal of Adolescent Health, 2007. Volume 40, Issue 4, 305 - 310.

4. Gouveia E, Freitas D, Maia J, et al. Prevalência de sobrepeso e obesidade em crianças e adolescentes da Região Autonoma da Madeira, Portugal. Acta Pediátrica Port 2009; 40:245-251.

5. Freitas D, Beunen G, Maia J, et al. Tracking of fatness during childhood, adolescence and young adulthood: a 7-year follow-up study in Madeira Island, Portugal. Ann Hum Biol 2012;38:59-67.

6. Rito A, Wijnhoven TM, Rutter H, et al. Prevalence of obesity among Portuguese children (6-8 years old) using three definition criteria: COSI Portugal, 2008. Pediatr Obes.2012;7:413-22. dii: 10.1111/j.2047-6310.2012.00068.x.

7. Wijnhoven TM, van Raaij JM, Spinelli A, et al. WHO European Childhood Obesity Surveillance Initiative 2008:weight, height and body mass index in 6-9-year-old children. Pediatr Obes 2013;8:79-97. doi:10.1111/j.2047-6310.2012.00090.x.

8. Wijnhoven TM, van Raaij JM, Spinelli A, et al. WHO European Childhood Obesity Surveillance Initiative: body mass index and level of overweight among 6-9-year-old children from school year 2007/2008 to school year 2009/2010. BMC Public Health. 2014;14:806.

9. Cole T, Bellizzi MC, Flegal KM, Dietz WH. Establishing a standard definition for child over-weight and obesity worldwide: international survey. BMJ 2000; 320: 1240- 1243 .

10. Curtis M. The obesity epidemic in the Pacific Islands. J Dev Soc Transform 2004; 1: 37-42.

11. Grech V, Farrugia Sant'Angelo V. Body mass index estimation in a school-entry aged cohort in Malta. Int J Pediatr Obes 2009; 4: $126-128$.

12. Schwiebbe L, van Rest J, Verhagen E, Visser RW, Holthe JK, Hirasing RA. Childhood obesity in the Carib- bean. West Indian Med J 2011 ; 60 : $442-445$.

13. Athanasopoulos DT, Garopoulou AI, Dragoumanos VP. Childhood obesity and associated fac-tors in a rural Greek island. Rural Remote Health 2011; 11: 1641 .

14. Garza JR, Pérez EA, Prelip M, et al. Occurrence and correlates of overweight and obesity among island Puerto Rican youth. Ethn Dis 2011; 21: 163-169.

15. SCHWIEBBE, L et al. Childhood obesity in the Caribbean. West Indian med. j. [online]. 2011, vol.60, n.4 [cited 2018-11-01], pp. 442-445 . Available from: $<$ http://caribbean.scielo.org/scielo.php?script=sci_arttext\&pid=S0043-31442011000400013\&lng=en\&nrm=iso $>$. ISSN 0043-3144.

16. Mazarello Paes V, Ong KK, Lakshman R Factors influencing obesogenic dietary intake in young children ( $0-6$ years): systematic review of qualitative evidence BMJ Open 2015;5:e007396. doi: 10.1136/bmjopen-2014-007396

17. Gina S. Lovasi, Malo A. Hutson, Monica Guerra, Kathryn M. Neckerman; Built Environments and Obesity in Disadvantaged Populations, Epidemiologic Reviews, Volume 31, Issue 1, 1 Novem-ber 2009, Pages 7-20, https://doi.org/10.1093/epirev/mxp005

18. Estudo sobre o poder de compra concelhio 2015. Instituto Nacional de Estatística, I.P. ed. 2017. Lisboa, Portugal.

19. Estratégia Local de Desenvolvimento do período de 2007-2013. Available from: https://proderam2020.madeira.gov.pt/images/noticias/2016/Desenvolvimento_Local_-_GAL/ELD_ACAPORAMA_26574.pdf

20. Michou M, Panagiotakos D, Costarelli V. Low health literacy and excess body weight: a sys-tematic review. Eur J Public Health 2018, 26(3):234-241 | DOI: $10.21101 /$ cejph.a5172

21. Ogden CL, Carroll MD, Kit BK, et al. Prevalence of obesity and trends in body mass index among US children and adolescents, 1999-2010. JAMA 2012;307:483-90.

22. de Onis M, Blössner M, Borghi E. Global prevalence and trends of overweight and obesity among preschool children. Am J Clin Nutr 2010;92:1257-64.

23. Camarinhas B, Graça P, Nogueira P. Prevalence of Pre-Obesity/Obesity in Pre and Basic School Children at Vila Nova de Gaia, Portugal. Acta Med Port 2016;29(1):31-40.

24. Cattaneo, A., Monasta, L., Stamatakis, E. , et al. Overweight and obesity in infants and pre-school children in the European Union: a review of existing data. Obesity Reviews, 2010;11: 389-398. doi:10.1111/j.1467-789X.2009.00639.x

25. Penilla C , Tschann J, Sanchez-Vaznaugh E, et al. Obstacles to preventing obesity in children aged 2 to 5 years: Latino mothers' and fathers' experiences and perceptions of their urban environ-ments.International Journal of Behavioral Nutrition and Physical Activity,2017; 14:148. DOI 10.1186/s12966017-0605-9

26. World Health Organization. Vienna Declaration on Nutrition and Noncommunicable Diseases in the Context of Health 2020. Viena:WHO; 2013. 